American Journal of Agricultural and Biological Sciences 4 (3): 242-248, 2009

ISSN 1557-4989

(C) 2009 Science Publications

\title{
Response of Maize to Nutrients Foliar Application Under Water Deficit Stress Conditions
}

\author{
${ }^{1}$ N.A. Sajedi, ${ }^{2}$ M.R. Ardakani, ${ }^{3}$ A. Naderi, ${ }^{4}$ H. Madani and ${ }^{5}$ M. Mashhadi Akbar Boojar \\ ${ }^{1}$ Islamic Azad University, Research and Science Branch, Ahvaz, Iran \\ ${ }^{2}$ Agriculture Research Center, Islamic Azad University, Karaj Branch, Iran \\ ${ }^{3}$ Faculty of Agriculture, Islamic Azad University, Research and Science Branch, Ahvaz, Iran \\ ${ }^{4}$ Faculty of Agriculture and Natural Resources, Islamic Azad University, Arak Branch, Iran \\ ${ }^{5}$ Department of Biology, Tarbiat Moallem University, Tehran, Iran
}

\begin{abstract}
Problem statement: To investigate the effect of nutrient application on agronomical characteristic and water use efficiency under water deficit stress of hybrid maize 704, an experiment was arranged in a split plot factorial based on a complete randomized block design with four replicates in the research station of Islamic Azad University-Arak Branch, Iran in 2007. Approach: Main factors studied were four irrigation levels including irrigation equal to crop water requirement, water deficit stress at eight- leaf stage $\left(V_{8}\right)$, stage of blister $\left(R_{2}\right)$ and stage of filling grain in the main plot. Combined levels of selenium treatment (without and with application $20 \mathrm{~g} \mathrm{ha}^{-1}$ ) were applied 2 weeks before execution of water stress treatment and micronutrients (without and with application) that was provided by specific fertilizer for maize called "Biomin", which contained $\mathrm{Fe}, \mathrm{Zn}, \mathrm{Cu}, \mathrm{Mn}, \mathrm{B}$, Mo and $\mathrm{Mg}$ in the form of foliar application at six-leaf stage and 1 week before tasseling stage at the rate of $2 \mathrm{~L} \mathrm{ha}^{-1}$ were situated in sub plots. Results: Results indicated that effect of water deficit stress on 1000 grain weight, grain yield, harvest index and water use efficiency at different growth stages was significant at $1 \%$ level. Water deficit stress decreased grain yield $33 \%$ in grain filling stage as compared with control. Using selenium increased mentioned traits but the increase was non significant. Effects of twofold interactions of water deficit stress and selenium showed that using selenium in water deficit stress condition increased measured traits as compared with treatment without selenium. A negative antagonistic interaction was found between selenium and micronutrients on some measured traits. In between treatments of water deficit stress, highest grain yield $\left(8159.33 \mathrm{~kg} \mathrm{ha}^{-1}\right)$ was obtained from combined treatment of water deficit stress at eight-leaf stage with selenium application and without micronutrients which compared with treatment of irrigation equal to crop water requirement, without selenium and microelements did not differ significant. Conclusion: According to the results of experiment, using microelements in optimum water availability and using selenium in water deficit stress condition increased mentioned traits as compared to treatments control.
\end{abstract}

Key words: water deficit, selenium, water use efficiency, grain yield

\section{INTRODUCTION}

Maize as a $\mathrm{C}_{4}$ plant, uptakes a large amount of nutrients from soil during its growth period. In many Asian countries (e.g., Iran) due to the calcareous nature of the soils, high $\mathrm{pH}$, low Organic Matter (OM), salty soil, continuous drought, high bicarbonates in the irrigation water and an imbalanced application of fertilizers ${ }^{[4]}$, plants growth most of the time affected by different abiotic limitations. Across the globe today, maize (Zea mays L.) is a direct staple food for millions of individuals and, through indirect consumption as a feed crop, is an essential component of global food security ${ }^{[8]}$. Drought and its consequent stress are one of the important factors which restrict agriculture production in Iran and reduce the use efficiency of dry lands. Therefore recognition and utilization crops tolerant to drought and the special crops improvement methods make it possible to use semi arid region ${ }^{[16]}$.

Significant yield losses occur due to water stress in both temperate and tropical environments of other continents that also provide maize for local and global

Corresponding Author: M.R. Ardakani, Agriculture Research Center, Islamic Azad University, Karaj Branch, Iran P.O. Box 31485-313 Karaj/Iran 
consumption $^{[8]}$. In order to stabilize and increase global maize production for a burgeoning world population, the development of maize varieties with enhanced drought tolerance continues to be an important objective. Maize producers in drought-prone areas of developing nations can often adopt plant breeding improvements more efficiently and effectively than high-input agronomic practices which often depend on input availability, appropriate infrastructure, market access and requisite crop and soil management skills ${ }^{[9]}$. Additionally, in many regions such as the lowland tropics, the use of drought-tolerant cultivars may be the only economical option for many small- scale farmers $^{[3]}$. Since water availability is variable across fields and producers typically grow only one hybrid in a particular field, a moderate amount of drought tolerance is necessary in all maize hybrids ${ }^{[5]}$. Thus, the development and adoption of drought-tolerant varieties is seen as a long-term solution to many of the problems plaguing drought-prone maize production regions around the globe ${ }^{[23]}$. In many arid and semiarid regions of the world, drought limits crop productivity. Soil water deficit reduces yield of maize and other grain crops by different mechanisms. Drought induced limitation of leaf area expansion, by temporary of wilting, or by early leaf senescence ${ }^{[33]}$. Drought stress may limit grain yield of maize by reducing the harvest index (HI, The fraction of crop dry matter allocated to the grain). This can occur even in the absence of a strong reduction in total crop dry matter accumulation, if a brief period of stress coincides with the critical developmental stage around silking. Developing ovaries appear to be weak sinks and will fail if there are insufficient new (concurrent) photosynthates available for their growth ${ }^{[2,30]}$. Alternatively water stress may prevent ovary fertilization by reducing silk receptivity ${ }^{[2]}$, or low kernel at ear potential may cause kernel growth to cease prematurely ${ }^{[15,30]}$. This latter effect may lead to a reduced HI even if water stress occurs late in the grain filling stage.

Selenium (Se) is a trace element with some important functions in living organisms, in particular in animals ${ }^{[22,32]}$. Although its role in the animal organism is known in detail, further investigation is required to elucidate its role in plants ${ }^{[5,14]}$. It is known that selenium occurs as selenate, selenite, selenide, elemental Se and organic selenium in the soil and that the uptake of selenium by plants is governed by many soil and plant factors $^{[34]}$. One of the most important factors determining the uptake of this element is the form and concentration of selenium in the soil $^{[5,14]}$. Selenium affects metal distribution and sometimes increases the excretion of toxic elements $^{[20]}$. In some plant species drought stimulates oxidation process which causes accumulation of poisonous oxygen such as free oxygen radical, Hydrogen peroxide and hydroxyl radicals. Variety of active oxygen forms which are produced through stress can damage such cellular constituents as, lipids, carbohydrates, proteins and nucleic acids. Oxidative stress can prevent photosynthetic activity, respiration process and plant growth. Plants are naturally provided by enzymatic and non-enzymatic systems to take care active oxygen ${ }^{[13]}$.

It is commonly accepted that macro- and microelements play significant roles in plant cells $^{[9,11,18,24]}$. The interactions between the elements in the soil and in plant organisms are very important and well known ${ }^{[10,24,28]}$.

Iron $(\mathrm{Fe})$ enters many plant enzymes that play dominant roles in oxidoredox reactions of photosynthesis and respiration. Iron participates in content of many enzymes: Cytochromes, ferredoxine, Superoxide Dismutase (SOD), Catalase (CAT), peroxidase and nitrate reductase. The deficiency of Fe in plants causes significant changes in the plant metabolism and induces chlorosis, especially in young leaves and leads to very low re-utilization ${ }^{[18]}$.

Manganese (Mn), in turn, is regarded as an activator of many different enzymatic reactions and takes part in photosynthesis. Manganese activates decarboxylase and dehydrogenase and is a constituent of complex PSII-protein, SOD and phosphatase. Deficiency of $\mathrm{Mn}$ induces inhibition of growth, chlorosis and necrosis, early leaf fall and low reutilization $^{[18]}$.

Copper $(\mathrm{Cu})$ is an essential micronutrient for plant metabolism, acts as a component of several enzymes and is involved in carbohydrates, $\mathrm{N}$ and cell wall metabolism. It is constituent of plastocyanine, cytochrome oxidase, tyrosinase, SOD and nitrate reductase. Deficiency of $\mathrm{Cu}$ induces chlorosis of leaves $^{[18]}$.

Zinc $(\mathrm{Zn})$ is an essential trace element for every living organism. About 200 enzymes and transcription factors require $\mathrm{Zn}$ as a functional component. This element plays an important role in protein and carbohydrate synthesis and takes part in metabolism regulation of saccharides, nucleic acid and lipid metabolism. One of the first symptoms of $\mathrm{Zn}$ deficiency is an inhibition of cell growth and proliferation. Zinc affects growth of shoots and roots and growth symptoms of $\mathrm{Zn}$ toxicity in plants, generally, are similar to those of $\mathrm{Zn}$ deficiency. The toxic concentrations of $\mathrm{Zn}$ negatively affect photosynthetic electron transport and photophosphorylation and have an effect on the photosynthetic enzymes. 
Am. J. Agri. \& Biol. Sci., 4 (3): 242-248, 2009

Table 1: Result of physical and chemical soil analysis

\begin{tabular}{|c|c|c|c|c|c|c|c|c|c|c|c|c|c|c|}
\hline Year & $\begin{array}{l}\text { Depth } \\
\text { (cm) }\end{array}$ & $\begin{array}{l}\text { EC } \\
{\text { ds } m^{-1}}^{2}\end{array}$ & $\mathrm{pH}$ & $\mathrm{OC}(\%)$ & $\mathrm{N}(\%)$ & $\begin{array}{l}\mathrm{P} \\
(\mathrm{ppm})\end{array}$ & $\begin{array}{l}\mathrm{K} \\
(\mathrm{ppm})\end{array}$ & $\begin{array}{l}\mathrm{Zn} \\
(\mathrm{ppm})\end{array}$ & $\begin{array}{l}\mathrm{Fe} \\
(\mathrm{ppm})\end{array}$ & $\begin{array}{l}\mathrm{Mn} \\
(\mathrm{ppm})\end{array}$ & $\begin{array}{l}\mathrm{Cu} \\
(\mathrm{ppm})\end{array}$ & $\begin{array}{l}\text { Sand } \\
(\%)\end{array}$ & $\begin{array}{l}\text { Silt } \\
(\%)\end{array}$ & $\begin{array}{l}\text { Clay } \\
(\%)\end{array}$ \\
\hline \multirow[t]{2}{*}{2007} & $0-30$ & 1.2 & 7.5 & 0.82 & 0.08 & 5.0 & 150 & 0.8 & 4.6 & 10.6 & 1.14 & 29 & 35 & 36 \\
\hline & $30-60$ & 1.7 & 7.4 & 0.61 & 0.061 & 3.6 & 120 & 0.4 & 4.0 & 6.6 & 0.88 & 27 & 29 & 44 \\
\hline
\end{tabular}

One of the primary mechanisms of $\mathrm{Zn}$ toxicity may be an increased permeability of root membranes, which will cause nutrients to leak out from the roots ${ }^{[18]}$. Application of microelements fertilizers can enhance plants resistance to environmental stresses such as drought and salinity ${ }^{[7]}$.

In this study, the effect of the selenite ion and microelements on some agrophysiological characteristics of maize has been studied under water deficit stress conditions.

\section{MATERIALS AND METHODS}

In order to study the effect of water deficit stress and nutrient elements application on kernel number per ear, 1000 kernel weight, grain yield, harvest index and water use efficiency in maize (KSC 704), a field experiment was carried out in the Research Station of Islamic Azad University, Arak Branch, Iran in 2007. The experimental design was split plot factorial based on complete randomized block design with four replications. Four irrigation levels including, without water stress (control), water deficit stress in Vegetative stage $\left(V_{8}\right)$, water deficit stress in blister stage $\left(R_{2}\right)$ and water deficit stress in grain filling stage $\left(R_{4}\right)$ were assigned to main plot and combination of $20 \mathrm{~g} \mathrm{ha}^{-1} \mathrm{Se}$ (without and with using sodium selenite-NaHSeO3) and microelements without and with using specific fertilizer for maize called "Biomin" which contained $\mathrm{Fe}, \mathrm{Zn}, \mathrm{Cu}$, $\mathrm{Mn}, \mathrm{B}, \mathrm{Mo}$ and $\mathrm{Mg}$ in the form of foliar application at six-leaf stage and one week before tasseling stage at the rate of 2 lit $\mathrm{ha}^{-1}$ were situated in sub plots that randomized to sub-plots. Soil preparation including ploughing was done in fall and perpendicular disks in May 2007. Each plot constituted seeded liners distanced $75 \mathrm{~cm}$ from each other and $20 \mathrm{~cm}$ distance between each two plants on the lines. The length of each seeded line was six meters and two furrows between each two plots were unseeded. Lines were hand-seeded on 18th of May 2007. One third of nitrogen and all of phosphorous fertilizers on the basis of soil analysis applied at sowing time and the remaining nitrogen fertilizer at two different periods during plant growth stages. Before sowing, combined soil samples to a 0-30 and 30-60 cm depth were collected and their physical and chemical properties were tested. Specifically, our test included determination $\mathrm{pH}$ using the hydrometry method $^{[12]}$ and of a saturated paste ${ }^{[29]}$, organic C (wet oxidation method) ${ }^{[26]}$, total $\mathrm{N}$ (Kjeldahl method) ${ }^{[25]}$ and the concentration of available $\mathrm{P}$ (sodium bicarbonate extraction method) ${ }^{[27]}$, available $\mathrm{K}$ (flame photometer method, emission spectrophotometry) ${ }^{[19]}$, Fe and $\mathrm{Mn}$ (Diethylenetriaminepentaacetic Acid (DTPA), using atomic absorption spectrometer, Model Perkin Elmer 3110) were determined (Table 1). Final harvest was performed at physiological maturity stage when a black layer was formed at seed base.

At maturity stage, grain yield was determined from a harvest area of $1.5 \times 4 \mathrm{~m}$ ( 2 rows middle of each experimental plot) and expressed on a $15 \%$ moisture basis. To determine water use efficiency the following relation was applied:

Water use economic efficiency $=$ Grain yield $\left(\mathrm{kg} \mathrm{ha}^{-1}\right) /$ water used $\left(\mathrm{m}^{3} \mathrm{ha}^{-1}\right)$

Mean comparison was conducted using Duncan's multiple range test ${ }^{[31]}$.

\section{RESULTS AND DISCUSSION}

Effects of water deficit stress on 1000 grain weight, grain yield, harvest index and water use efficiency at different growth stages was significant at $1 \%$ level. Mean comparison of treatments indicate that highest rate of 1000 grain weight, grain yield, harvest index and water use efficiency related to treatment of without water deficit stress and the lowest grain yield, harvest index and water use efficiency belonged to plants under water deficit stress in grain filling stage (Table 2). Water deficit stress decreased grain yield $12.75 \%$ in stage $\mathrm{V}_{8}, 16.3 \%$ in stage of blister and $33 \%$ in stage of grain filling as compared with control. In seed filling period, reducing growth period irregularities in transfer of photosynthetic materials caused by water deficit, will effect on seed weights as one of the yield components. Decrease in grain yield can due to reduced leaf, silk and grain kernel expansion, reduced assimilate flux to growing organs, accelerated leaf senescence, delayed silk growth and greater ear and kernel abortion ${ }^{[2]}$. Also result of this research is parallel with results of other researchers $^{[2,3,21,30]}$.

Effect of selenium on grain yield, harvest index and water use efficiency was not significant, but with using selenium mentioned traits, were increased. 
Application of selenium increased grain yield $2.1 \%$ in compared with control (Table 2). This is important from viewpoint of quantity and quality for consumption human and animals.

Application of microelements decreased kernel number per ear and grain yield significantly at 5\% level, but on 1000 grain weight, harvest index and water use efficiency was not significant. This may be related to antagonistic interaction of microelements to each other. In maize, with copper application alone and along with iron and manganese decreased kernel number per ear, 1000 grain weight and grain yield ${ }^{[17]}$.

Results of two fold interactions water deficit stress and selenium on grain yield, harvest index and water use efficiency was significant. Highest seed yield was obtained from control treatment (Without stress and without Selenium) which showed significant differences in compared to other treatments. Using selenium in water deficit stress condition increased mentioned traits as compared to treatment without using selenium. In between treatments of stress, the highest magnitude of measured traits was found from treatment of water deficit stress in stage $V_{8}$. Least grain yield under water deficit was obtained from treatment of water deficit stress in grain filling stage and without Selenium application (Table 3). This might be indicative of plant sensitivity due to no protection factor under water stress. Using microelements in water optimum conditions increased traits measured as compared to without microelements but in water deficit stress conditions in all growth stages, all of traits were decreased. Presumable in water deficit stress condition due to increasing of concentration these elements in plant toxicity created.

Table 2: Mean comparison of main and interaction effects of characters on Kernel Number per ear (KNE), 1000 grain weight (1000 GW), Grain Yield (GY), Harvest Index (HI) and Water Use Efficiency (WUE)

\begin{tabular}{|c|c|c|c|c|c|}
\hline Treatment & KNE & $1000 \mathrm{gw}(\mathrm{g})$ & GY $\left(\mathrm{kg} \mathrm{ha}^{-1}\right)$ & $\mathrm{HI}(\%)$ & WUE $\left(\mathrm{kg} \mathrm{m}^{-3}\right)$ \\
\hline \multicolumn{6}{|l|}{ Water limitation: } \\
\hline $\mathrm{L}_{1}$ & $503.26 \mathrm{a}$ & $199.66 \mathrm{a}$ & $8024.87 \mathrm{a}$ & $53.39 \mathrm{a}$ & $0.95 \mathrm{a}$ \\
\hline $\mathrm{L}_{2}$ & $403.62 \mathrm{~b}$ & $194.66 \mathrm{a}$ & $6989.19 \mathrm{~b}$ & $48.51 \mathrm{~b}$ & $0.97 \mathrm{a}$ \\
\hline $\mathrm{L}_{3}$ & 438.44ab & $174.97 \mathrm{~b}$ & $6712.08 \mathrm{~b}$ & $47.94 \mathrm{~b}$ & $0.93 \mathrm{a}$ \\
\hline $\mathrm{L}_{4}$ & $471.92 \mathrm{ab}$ & $142.66 \mathrm{c}$ & $5385.73 \mathrm{c}$ & $44.59 \mathrm{~b}$ & $0.75 \mathrm{~b}$ \\
\hline \multicolumn{6}{|l|}{ Selenium: } \\
\hline $\mathrm{Se}_{0}$ & $448.39 \mathrm{a}$ & $175.97 \mathrm{a}$ & $6703.49 \mathrm{a}$ & $48.50 \mathrm{a}$ & $0.88 \mathrm{a}$ \\
\hline $\mathrm{Se}_{1}$ & $460.22 \mathrm{a}$ & $180.00 \mathrm{a}$ & $6852.45 \mathrm{a}$ & $48.73 a$ & $0.91 \mathrm{a}$ \\
\hline \multicolumn{6}{|l|}{ Microelement: } \\
\hline $\mathrm{M}_{0}$ & $466.61 \mathrm{a}$ & $178.26 \mathrm{a}$ & $6938.41 \mathrm{a}$ & $48.66 \mathrm{a}$ & $0.92 \mathrm{a}$ \\
\hline $\mathrm{M}_{1}$ & $442.01 \mathrm{~b}$ & $177.70 \mathrm{a}$ & $6617.53 \mathrm{~b}$ & $48.56 \mathrm{a}$ & $0.87 \mathrm{a}$ \\
\hline
\end{tabular}

Mean followed by the same letters in each column are not significantly (Duncan s multiple rang test 5\%): $\mathrm{L}_{1}$ : Optimum condition: $\mathrm{M}_{0}$ : Without microelement; $\mathrm{L}_{2}$ : Water limitation inV8 stages; $\mathrm{M}_{1}$ : With microelement; $\mathrm{L}_{3}$ : Water limitation in blister stages; $\mathrm{Se}_{0}$ : Without selenium; $\mathrm{L}_{4}$ : Water limitation in dough stages; $\mathrm{Se}_{1}$ : With selenium

Table 3: Mean comparison of twofold interaction effects of characters on Kernel Number per Ear (KNE), 1000 Grain Weight (1000 GW), Grain Yield (GY), Harvest Index (HI) and Water Use Efficiency (WUE)

\begin{tabular}{|c|c|c|c|c|c|c|}
\hline Treatment & & KNE & $1000 \mathrm{kw}(\mathrm{g})$ & $\mathrm{GY}\left(\mathrm{kg} \mathrm{ha}^{-1}\right)$ & $\mathrm{HI}(\%)$ & WUE $\left(\mathrm{kg} \mathrm{m}^{-3}\right)$ \\
\hline Water limitation & Selenium & & & & & \\
\hline \multirow[t]{2}{*}{$\mathrm{L}_{1}$} & $\mathrm{Se}_{0}$ & $516.75 \mathrm{a}$ & 206.16a & $9143.88 \mathrm{a}$ & $55.09 \mathrm{a}$ & $1.08 \mathrm{a}$ \\
\hline & $\mathrm{Se}_{1}$ & $489.77 \mathrm{a}$ & $183.13 b c$ & $6904.86 \mathrm{bc}$ & $51.70 \mathrm{ab}$ & $0.82 \mathrm{c}$ \\
\hline \multirow[t]{2}{*}{$\mathrm{L}_{2}$} & $\mathrm{Se}_{0}$ & $393.28 \mathrm{c}$ & 198.70ab & $6617.66 \mathrm{c}$ & $47.19 \mathrm{bc}$ & $0.92 \mathrm{~b}$ \\
\hline & $\mathrm{Se}_{1}$ & $411.51 b c$ & $200.62 \mathrm{ab}$ & $7360.72 b$ & $49.83 \mathrm{bc}$ & $1.02 \mathrm{a}$ \\
\hline \multirow[t]{2}{*}{$\mathrm{L}_{3}$} & $\mathrm{Se}_{0}$ & $439.30 \mathrm{~b}$ & $166.98 \mathrm{~cd}$ & $6594.80 \mathrm{c}$ & $49.83 \mathrm{bc}$ & $0.91 \mathrm{~b}$ \\
\hline & $\mathrm{Se}_{1}$ & $437.59 \mathrm{~b}$ & $182.96 b c$ & $6829.35 \mathrm{bc}$ & $49.32 \mathrm{bc}$ & $0.94 b$ \\
\hline \multirow{2}{*}{$\mathrm{L}_{4}$} & $\mathrm{Se}_{0}$ & $444.24 \mathrm{~b}$ & $132.04 \mathrm{e}$ & $4457.60 \mathrm{~d}$ & $42.39 \mathrm{~d}$ & $0.62 \mathrm{~d}$ \\
\hline & $\mathrm{Se}_{1}$ & $499.59 \mathrm{a}$ & $153.29 \mathrm{~d}$ & $63 \ln 3.87 \mathrm{c}$ & $46.79 \mathrm{~cd}$ & $0.87 \mathrm{~b}$ \\
\hline Water limitation & Microelement & & & & & \\
\hline \multirow{2}{*}{$\mathrm{L}_{1}$} & $\mathrm{M}_{0}$ & $505.13 \mathrm{a}$ & $178.97 b c$ & $7841.27 \mathrm{a}$ & $52.31 \mathrm{ab}$ & $0.93 \mathrm{ab}$ \\
\hline & $\mathrm{M}_{1}$ & $501.38 \mathrm{a}$ & $210.31 \mathrm{a}$ & $8208.47 a$ & $54.47 \mathrm{a}$ & $0.97 \mathrm{ab}$ \\
\hline \multirow[t]{2}{*}{$\mathrm{L}_{2}$} & $\mathrm{M}_{0}$ & $418.62 b$ & $204.69 \mathrm{a}$ & $7152.66 \mathrm{~b}$ & $47.72 \mathrm{bc}$ & $0.99 \mathrm{a}$ \\
\hline & $\mathrm{M}_{1}$ & $388.62 b$ & 194.64ab & $6825.72 b c$ & $49.31 \mathrm{bc}$ & $0.95 \mathrm{ab}$ \\
\hline \multirow[t]{2}{*}{$\mathrm{L}_{3}$} & $\mathrm{M}_{0}$ & $476.58 \mathrm{~b}$ & $182.14 b c$ & $6994.74 b c$ & $47.40 \mathrm{c}$ & $0.97 \mathrm{ab}$ \\
\hline & $\mathrm{M}_{1}$ & $400.31 \mathrm{~b}$ & $182.14 b c$ & $6429.41 \mathrm{c}$ & $48.49 \mathrm{bc}$ & $0.89 \mathrm{~b}$ \\
\hline \multirow[t]{2}{*}{$\mathrm{L}_{4}$} & $\mathrm{M}_{0}$ & $466.09 \mathrm{a}$ & $147.25 \mathrm{~d}$ & $5764.96 \mathrm{~d}$ & $47.22 \mathrm{c}$ & $0.80 \mathrm{c}$ \\
\hline & $\mathrm{M}_{1}$ & $477.74 \mathrm{a}$ & $138.07 \mathrm{~d}$ & $5006.51 \mathrm{e}$ & $41.96 \mathrm{~d}$ & $0.70 \mathrm{~b}$ \\
\hline Selenium & Microelement & & & & & \\
\hline \multirow[t]{2}{*}{$\mathrm{Se}_{0}$} & $\mathrm{M}_{0}$ & $459.16 \mathrm{a}$ & $176.71 \mathrm{a}$ & $6717.35 b$ & $49.00 \mathrm{a}$ & $0.88 \mathrm{~b}$ \\
\hline & $\mathrm{M}_{1}$ & $437.16 \mathrm{a}$ & $175.23 \mathrm{a}$ & $6689.62 b$ & $48.00 \mathrm{a}$ & $0.88 b$ \\
\hline \multirow[t]{2}{*}{$\mathrm{Se}_{1}$} & $\mathrm{M}_{0}$ & $473.59 \mathrm{a}$ & $179.82 \mathrm{a}$ & $7159.46 a$ & $48.33 a$ & $0.96 a$ \\
\hline & $\mathrm{M}_{1}$ & $446.86 \mathrm{a}$ & $180.17 \mathrm{a}$ & $6545.43 b$ & $49.12 \mathrm{a}$ & $0.87 \mathrm{~b}$ \\
\hline
\end{tabular}

Mean followed by the same letters in each column are not significantly (Duncan multiple rang test 5\%)\%): $\mathrm{L}_{1}$ : Optimum condition: $\mathrm{M}_{0}$ : Without microelement; $\mathrm{L}_{2}$ : Water limitation inV8 stages; $\mathrm{M}_{1}$ : With microelement; $\mathrm{L}_{3}$ : Water limitation in blister stages; $\mathrm{Se}_{0}$ : Without selenium; $\mathrm{L}_{4}$ : Water limitation in dough stages; $\mathrm{Se}_{1}$ : With selenium 
Am. J. Agri. \& Biol. Sci., 4 (3): 242-248, 2009

Table 4: Mean comparison of threefold interaction effects of characters on Kernel Number per Ear (KNE), 1000 Grain Weight (1000 GW), Grain Yield (GY), Harvest Index (HI) and Water Use Efficiency (WUE)

\begin{tabular}{|c|c|c|c|c|c|c|c|}
\hline \multicolumn{8}{|c|}{ Treatment } \\
\hline \multicolumn{3}{|c|}{ Water limitation/selenium/microelement } & \multirow{2}{*}{$\begin{array}{l}\text { KNE } \\
526.40 \mathrm{a}\end{array}$} & \multirow{2}{*}{$\frac{1000 \mathrm{kw}(\mathrm{g})}{199.74 \mathrm{abc}}$} & \multirow{2}{*}{$\frac{\mathrm{GY}\left(\mathrm{kg} \mathrm{ha}^{-1}\right)}{8768.72 \mathrm{ab}}$} & \multirow{2}{*}{$\frac{\mathrm{HI}(\%)}{54.15 \mathrm{ab}}$} & \multirow{2}{*}{$\frac{\text { WUE }\left(\mathrm{kg} \mathrm{m}^{-3}\right)}{1.03 \mathrm{ab}}$} \\
\hline$\overline{\mathrm{L}_{1}}$ & $\mathrm{Se}_{0}$ & $\mathrm{M}_{0}$ & & & & & \\
\hline & $\mathrm{Se}_{0}$ & $\mathrm{M}_{1}$ & $507.10 \mathrm{ab}$ & $212.56 a$ & $9519.05 \mathrm{a}$ & $56.03 \mathrm{a}$ & $1.11 \mathrm{a}$ \\
\hline & $\mathrm{Se}_{1}$ & $\mathrm{M}_{0}$ & $483.87 \mathrm{abc}$ & $158.19 \mathrm{efg}$ & $6913.83 \mathrm{cde}$ & 50.47abcde & $0.82 \mathrm{ef}$ \\
\hline & $\mathrm{Se}_{1}$ & $\mathrm{M}_{1}$ & $495.67 \mathrm{abc}$ & $208.06 \mathrm{ab}$ & $6897.90 \mathrm{cde}$ & $52.92 \mathrm{abc}$ & $0.82 \mathrm{f}$ \\
\hline \multirow[t]{4}{*}{$\mathrm{L}_{2}$} & $\mathrm{Se}_{0}$ & $\mathrm{M}_{0}$ & $391.14 \mathrm{f}$ & $201.53 \mathrm{abc}$ & 6146.00def & $46.42 \mathrm{cdef}$ & $0.86 \mathrm{def}$ \\
\hline & $\mathrm{Se}_{0}$ & $\mathrm{M}_{1}$ & $395.43 \mathrm{ef}$ & $195.88 \mathrm{abc}$ & $7089.33 \mathrm{~cd}$ & 47.97bcde & $0.99 \mathrm{bc}$ \\
\hline & $\mathrm{Se}_{1}$ & $\mathrm{M}_{0}$ & $446.10 \mathrm{bcdef}$ & $207.85 \mathrm{ab}$ & $8159.33 b$ & 49.02abcde & $1.13 \mathrm{a}$ \\
\hline & $\mathrm{Se}_{1}$ & $\mathrm{M}_{1}$ & $381.80 \mathrm{f}$ & 193.39abcd & $6562.11 \mathrm{cdef}$ & $50.65 \mathrm{abcde}$ & $0.91 \mathrm{cdef}$ \\
\hline \multirow[t]{4}{*}{$\mathrm{L}_{3}$} & $\mathrm{Se}_{0}$ & $\mathrm{M}_{0}$ & $489.23 \mathrm{abc}$ & $175.85 \mathrm{cde}$ & $7242.94 c$ & 51.08abcd & $1.00 \mathrm{bc}$ \\
\hline & $\mathrm{Se}_{0}$ & $\mathrm{M}_{1}$ & $389.37 \mathrm{f}$ & 158.12efg & $5946.66 \mathrm{ef}$ & 47.56bcde & $0.82 \mathrm{ef}$ \\
\hline & $\mathrm{Se}_{1}$ & $\mathrm{M}_{0}$ & 463.93abcd & 188.44abcd & $6746.55 \mathrm{cdef}$ & $43.72 \mathrm{ef}$ & 0.93 bcde \\
\hline & $\mathrm{Se}_{1}$ & $\mathrm{M}_{1}$ & $411.25 \mathrm{def}$ & $177.47 \mathrm{bcde}$ & $6912.16 \mathrm{cde}$ & 49.41abcde & $0.96 \mathrm{bcd}$ \\
\hline \multirow[t]{4}{*}{$\mathrm{L}_{4}$} & $\mathrm{Se}_{0}$ & $\mathrm{M}_{0}$ & $431.73 \mathrm{cdef}$ & $129.70 \mathrm{~g}$ & $4711.77 \mathrm{~g}$ & 44.34def & $0.65 \mathrm{~g}$ \\
\hline & $\mathrm{Se}_{0}$ & $\mathrm{M}_{1}$ & $456.76 \mathrm{bcde}$ & $134.38 \mathrm{~g}$ & $4202.44 \mathrm{~g}$ & $40.44 \mathrm{f}$ & $0.61 \mathrm{~g}$ \\
\hline & $\mathrm{Se}_{1}$ & $\mathrm{M}_{0}$ & $500.46 \mathrm{ab}$ & $164.80 \mathrm{def}$ & $6818.16 \mathrm{cde}$ & 50.09abcde & $0.94 \mathrm{bcd}$ \\
\hline & $\mathrm{Se}_{1}$ & $\mathrm{M}_{1}$ & 498.73ab & $141.77 \mathrm{fg}$ & $5809.58 \mathrm{f}$ & $43.49 \mathrm{ef}$ & $0.80 \mathrm{f}$ \\
\hline
\end{tabular}

Mean followed by the same letters in each column are not significantly (Duncan multiple rang test 5\%) \%): $\mathrm{L}_{1}$ : Optimum condition: $\mathrm{M}_{0}$ : Without microelement; $\mathrm{L}_{2}$ : Water limitation inV8 stages; $\mathrm{M}_{1}$ : With microelement; $\mathrm{L}_{3}$ : Water limitation in blister stages; $\mathrm{Se}_{0}$ : Without selenium; $\mathrm{L}_{4}$ : Water limitation in dough stages; $\mathrm{Se}_{1}$ : With selenium

A negative antagonistic interaction was found between selenium and microelements in traits of kernel number per ear, grain yield and water use efficiency but 1000 grain weight and harvest index were increased with using both selenium and microelements not significantly (Table 3). Decrease in amount of these traits may be due to antagonistic interaction between microelements and selenium.

Three fold interactions experimental factors had significant effect on grain yield and water use efficiency.

The highest amounts of 1000 grain weight $(212.56 \mathrm{~g})$, grain yield $\left(9519.05 \mathrm{~kg} \mathrm{ha}^{-1}\right)$, harvest index $(56.03 \%)$ and water use efficiency $\left(1.11 \mathrm{~kg} \mathrm{~m}^{-3}\right)$ obtain from treatment of water optimum conditions + without selenium + with microelements (Table 4). Using selenium and microelements alone in water deficit stress conditions in vegetative growth stage and dough stage increased grain yield, water use efficiency in compared to without using this elements in water stress conditions (Table 4). Presumable in the end of growth period that increased stress conditions, selenium and microelements with take part in biological activity of cells, induced health protection and permanent in function of membranes. In general, it is concluded that by using selenium and microelements under water stress can yield better as compared to without using this elements. Microelements take part in protein synthesis, metabolism regulation of saccharides, nucleic acid and lipid metabolism. Enters the oxidoredoctase enzymes, acts as a component of several enzymes: Superoxide Dismutase (SOD), catalase, peroxidase and nitrate reductase and cytochromes, ferredoxine. Therefore when plants are deficient of these elements, activities of antioxidant enzymes decrease imposing and increased sensitivity to environmental stresses.

\section{CONCLUSION}

Long-term trends in global climate change and the expansion of maize production into marginal areas are generating a greater number of drought-prone maize production environments across the globe. Increases in global temperatures as a result of rising greenhouse gas concentrations could potentially accelerate maize growth and development, hasten maturity and reduce soil moisture. Improvements in maize drought tolerance are therefore vital for maintaining local and global food security. In general, plants tolerated unfavorable environmental conditions by changing their morphology as living indices. Selenium as necessary trace element for living organisms is an essential component for activity of antioxidant enzymes system. With using selenium traits of grain yield, harvest index and water use efficiency increased. Use of selenium in water deficit stress condition increased grain yield, harvest index and water use efficiency significantly. Other microelements such as $\mathrm{Fe}, \mathrm{Zn}, \mathrm{Cu}, \mathrm{Mg}$ and $\mathrm{Mn}$ also play their role as cofactors in the structure of many antioxidant enzymes, therefore when plants are deficient of these elements activities of antioxidant enzymes decrease imposing increased sensitivity to environmental stresses. Using microelements in water optimum condition increased traits measured as 
compared to without microelements but in water deficit stress condition in all growth stages traits were decreased. Using of selenium and microelements in water deficit stress condition in vegetative growth stage and dough stage increased yield, water use efficiency as compared to without using this elements in water stress condition.

The combined results of these studies indicate that by using selenium and microelements under water stress can produce stable yield as compared to without using this elements.

\section{REFERENCES}

1. Bnziger, M., G.O. Edmeades, D. Beck and M. Bellon, 2000. Breeding for Drought and Nitrogen Stress Tolerance in Maize: From Theory to Practice. CIMMYT., Mexico DF., ISBN: 9706480463, pp: 68.

2. Bassetti, P. and M.E. Westgate, 1993. Water deficit affects receptivity of maize silks. Crop Sci., 33: 279-282.

http://crop.scijournals.org/cgi/content/abstract/33/2/279

3. Bolaos, J.B. and G.O. Edmeades, 1993. Eight cycles of selection for drought tolerance in lowland tropical maize. I. Responses in grain yield, biomass and radiation utilization. Field Crops Res., 31: 233-252. http://www.fao.org/agris/search/display.do?f=./199 3/v1902/NL9300475.xml;NL9300475

4. Bradl, H.B., 2004. Adsorption of heavy metal Probability level ions on soils and soils constituents. J. Colloid Interface Sci., 277: 1-18. DOI: 10.1016/j.jcis.2004.04.005

5. Brown, T.A. and A. Shrift, 1989. Selenium toxicity and tolerance in higher plants. Biol. Rev., 57: 59-84. DOI: 10.1111/j.1469-185X.1982.tb00364.x

6. Bruce, W.B., G.O. Edmeades and T.C. Barker, 2002. Molecular and physiological approaches to maize improvement for drought tolerance. J. Exp. Bot., 53:13-25. http://www.ncbi.nlm.nih.gov/pubmed/11741036

7. Cakmak, I., 2000. Possible roles of zinc in protecting plant cells from damage by reactive oxygen species. N. Phytol., 146, 2: 85-200. http://cat.inist.fr/?aModele=afficheN\&cpsidt $=1357141$

8. Campos, H., M. Cooper, J.E. Habben, G.O. Edmeades and J.R. Schussler, 2004. Improving drought tolerance in maize: A view from industry. Field Crops Res., 90: 19-34. http://cat.inist.fr/?aModele=afficheN\&cpsidt=16142351

9. Canny, M.J., 1984. Translocation of Nutrients and Hormones. In: Advanced Plant Physiology, Wilkins, M.B. (Ed.). Pitman Publishing, London, UK., ISBN: 0273018531, pp: 277-296.
10. Feroci, G., A. Fini, R. Badiello and A. Breccia, 1997. Interaction between selenium derivatives and heavy metal ions: $\mathrm{Cu}^{2+}$ and $\mathrm{Pb}^{2+}$. Microchem. J., 57: 379-388. DOI: 10.1006/mchj.1997.1494

11. Fox, T.C. and M.L. Guerinot, 1998. Molecular biology of cation transport in plants. Ann. Rev. Plant Physiol. Plant Mol. Biol., 49: 669-696. http://www.ncbi.nlm.nih.gov/pubmed/15012250

12. Gee, G.W. and J.W. Bauder, 1986. Particle-Size Analysis Part 1, In: Methods of Soil Analysis, Klute, A. (Ed.). 2nd Edn., Agronomy Monographs, Madison, WI., ASA and SSSA., pp: 383-411.

13. Giang, Y. and B. Huang, 2001. Drought and heat stress injury two cool-season turf grasses in relation to antioxidant metabolism and lipid peroxidation. Crop Sci., 41: 436-442. http://cat.inist.fr/?aModele $=$ afficheN\&cpsidt $=9524$ 56

14. Giessel-Nielsen, G., U.C. Gupta, M. Lamand and T. Westermarck, 1984. Selenium in soils and plants. Adv. Agron., 37: 397-460

15. Grant, R.L.F., B.C. Jackson, J.R. Kiniry and G.F. Aarkin, 1989. Water deficit timing effects on yield components in maize. Agron. J., 81: 61-65. http://cat.inist.fr/?aModele $=$ afficheN\&cpsidt $=7348$ 591

16. Habibi, D., M.R. Ardakani, M.M. Boojar, D.F. Taleghani and A. Mahmodi, 2004. Antioxidative in sunflower subjected to drought stress. http://www.cropscience.org.au/icsc2004/poster/1/3/ 4/594_habibid.htm

17. Himayatullah and M. Khan, 1998. Response of irrigated maize to trace elements in the presence of NPK sarhad. J. Agric., 14: 117-120.

18. Kabata-Pendias, A. and H. Pendias, 1999. Biogeochemistry of Trace Elements. PWN, Warsaw, Poland, pp: 398.

19. Knudsen, D., G.A. Peterson and P.F. Pratt, 1982. Lithium, Sodium and Potassium. In: Methods of Soil Analysis, Chemical and Microbiological Properties, Page, A.L. et al. (Ed.). ASA Monograph Number, ISBN: 10: 0891180729, pp: 225-246.

20. Landberg, T. and H. Greger, 1994. Influence of selenium on uptake and toxicity of copper and cadmium in pea and wheat. Physiol. Plant 90: 637-644. DOI: $\quad$ 10.1111/j.13993054.1994.tb02518.x 
21. Laffitte, H.R. and G.O. Edmeades, 1995. Stress tolerance in tropical maize is linked to constitutive change in ear growth haracteristics. Crop Sci., 3: 820-826.

http://cat.inist.fr/?aModele $=$ afficheN\&cpsidt $=3523$ 523

22. Levander, O.A., 1982. Selenium: Biochemical Actions, Interactions and Some Human, Health Implications. Clinical, Biochemical and Nutritional Aspects of Trace Elements. Elsevier, New York, pp: 345-368.

23. Logroño, M.L. and J.E. Lothrop, 1997. Impact of Drought and Low Nitrogen on Maize Production in South Asia. In: Developing Drought and Low-N Tolerant Maize, Edmeades, G.O., M. Bunziger, H.R. Mickelson and C.B. Pẽna-Valdivia (Eds.). CIMMYT, El Batan, Mexico, ISBN: 9686923934, pp: 39-43.

24. Loneragan, I.F. and M.J. Webb, 1993. Interactions between zinc and other nutrients affecting the growth of plants. Soil Sci. Soc. Am. J., 46: 345-352.

25. Nelson, D.W. and L.E. Sommers, 1973. Determination of total nitrogen in plant material. Agron. $\quad$ J., $\quad 65$ : 109-112. http://agron.scijournals.org/cgi/content/abstract/65/ $1 / 109$

26. Nelson, D.W. and L.E. Sommers, 1982. Total Carbon, Organic Carbon and Organic Matter. In: Methods of Soil Analysis, Page A.L., R.H. Miller, D.R. Keeney (Eds.). 2nd Edn., American Society of Agronomy, Madison, WI., USA., pp: 539-573.

27. Olsen, R.S., 1954. Estimation of available phosphorus.

http://cropandsoil.oregonstate.edu/sites/default/file s/WERA103/Methods/WCC-103-Manual-2003-

Soil_P,K,Ca,Mg,Na.pdf

28. Pazurkiewicz-Kocot, K., W. Galas and A. Kita, 2002. The effect of selenium on the accumulation of some metals in Zea mays L. plants treated with indole-acetic acid. Cell. Mol. Biol. Lett., 8: 97-103. http://www.cmbl.org.pl/pdf/Vol7_suppl_07_63.pdf
29. Rhoades, J.D., 1982. Soluble Salts. In: Methods of Soil Analysis, Part 2, Page, A.L., R.H. Miller, D.R. Keeney (Eds.). 2nd Edn., American Society of Agronomy, Madison, WI., USA., ISBN: 089118-072-9, pp: 167-178.

30. Schussler, J.R. and M.E. Westgate, 1995. Assimilate flux determines kernel set at low water potential in maize. Crop Sci., 35: 1074-1080. http://crop.scijournals.org/cgi/content/abstract/35/4 $/ 1074$

31. Steel, R.G.D and H.J. Torrie, 1980. Principles and Procedures of Statistics: A Biometrical Approach. 2nd Edn., McGraw Hill, New York, USA., ISBN: 0070665818 , pp: 633.

32. Wachowicz, B., H.M. Żbikowska and P. Nowak, 2001. Selenium compounds in the environment; their effect on human health. Cell. Mol. Biol. Lett., 6: 375-381.

http://direct.bl.uk/bld/PlaceOrder.do?UIN=102915 $732 \&$ ETOC $=$ RN\& from $=$ searchengine

33. Xianshi, G., T.R. Sinclair and J.D. Ray, 1998. Effect of drought history on recovery of transpiration, photosynthesis and leaf area development in maize soil. Crop Sci. Soc. Florida, 57: 83-86.

http://direct.bl.uk/bld/PlaceOrder.do?UIN=073637 $387 \&$ ETOC $=$ RN\&from $=$ searchengine

34. Yamada, H., Y. Kang, T. Aso, H. Uesugi, T. Fujimura and K. Yonebayashi, 1998. Chemical forms and stability of selenium in soil. Soil Sci. Plant Nutr. 44: 385-391. http://cat.inist.fr/?aModele $=$ afficheN\&cpsidt $=1709$ 093 